Abstracta Iranica Abstracta Iranica

Revue bibliographique pour le domaine irano-aryen

Volume 31 | 2011

Comptes rendus des publications de 2008

\title{
Khojilär jämiyäti häqqidä. Trad. Qurban Turan, Pékin, Millätlär näshriyati, 2006, 526 p. [Au sujet du groupe des Khwāja]
}

\section{Alexandre Papas}

\section{(2) OpenEdition}

Journals

Édition électronique

URL : http://journals.openedition.org/abstractairanica/39588

DOI : 10.4000/abstractairanica.39588

ISSN : 1961-960X

Éditeur :

CNRS (UMR 7528 Mondes iraniens et indiens), Éditions de l'IFRI

\section{Édition imprimée}

Date de publication : 15 mai 2011

ISSN : 0240-8910

\section{Référence électronique}

Alexandre Papas, « Khojilär jämiyäti häqqidä. Trad. Qurban Turan, Pékin, Millätlär näshriyati, 2006, 526

p. [Au sujet du groupe des Khwāja] », Abstracta Iranica [En ligne], Volume 31 | 2011, document 171, mis en ligne le 11 octobre 2012, consulté le 02 octobre 2020. URL : http://journals.openedition.org/ abstractairanica/39588; DOI : https://doi.org/10.4000/abstractairanica.39588

Ce document a été généré automatiquement le 2 octobre 2020.

Tous droits réservés 


\title{
Khojilär jämiyäti häqqidä. Trad. Qurban Turan, Pékin, Millätlär näshriyati, 2006, 526 p. [Au sujet du groupe des Khwāja]
}

\author{
Alexandre Papas
}

Ce livre est la traduction en langue ouïgoure de Liu Zhengyin et Wei Liangtao, Xiyu hezhuo jiazu yanjiu [Les Khwāja de la région de l'ouest], Pékin, Zhongguo shehuikexue chubanshe, 1998. Il retrace l'histoire de la dynastie naqšbandì des Khwāja au Turkestan oriental de la fin du XVI ${ }^{\mathrm{e}} \mathrm{s}$. jusqu'à la conquête mandchoue en 1759. L'ouvrage n'est pas dénué de qualités: il propose une synthèse claire de cette histoire compliquée, sa chronologie est précise. Les sources chinoises fournissent des éléments de contexte intéressants mais elles sont, pour la plupart, postérieures à la période (une liste détaillée est donnée p. 18-48). Une lecture plus fine tirerait de ces textes les éléments d'un discours colonial naissant. Les AA. ne font pas l'impasse sur les sources primaires centrasiatiques en persan et en turc oriental. Hélas, elles sont utilisées de façon parcimonieuse et ne comprennent pas un certain nombre de textes essentiels (Hidāyat

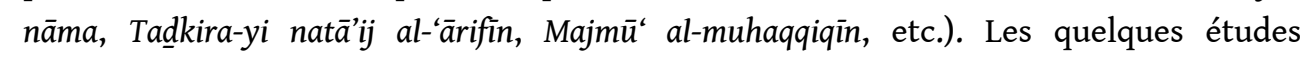
secondaires citées ne comptent ni les travaux, pourtant incontournables, de Joseph Fletcher ni ceux de Sawada Minoru; les nombreux articles et livres publiés dans les langues turques (turc, ouzbek, ouigour) sont totalement absents. Cet autisme scientifique explique en partie l'approche historiographique privilégiée par les auteurs : loin de renouer les fils politico-religieux de cette période bien spécifique, sans jamais reconstituer le système idéologique auquel les acteurs se réfèrent, on se contente d'enchaîner les descriptions d'événements en recourant aux seuls poncifs du fanatisme et du féodalisme religieux. Une telle vision de l'histoire, réductrice et obsolète, est annoncée dès les premiers chapitres - 150 pages de préambule plus ou moins inutile qui expliquent l'islam, le soufisme et la Naqšbandiyya sur un mode purement factuel, souvent superficiel. 
2 Cette mise au point me paraît nécessaire dans la mesure où il se trouve encore quelques sinologues visiblement mal informés qui persistent à conseiller cet ouvrage (voir Archives des Sciences Sociales des Religions 136, 2006, p. 82). N'était le respect que je dois aux études chinoises, la recommandation me semble peu recommandable et désespérément naïve.

INDEX

Thèmes : 4.2.2. Asie centrale

\section{AUTEURS}

\section{ALEXANDRE PAPAS}

CNRS - Paris 